\title{
A Jewish Feast: The Annual Feast of Rabbi Simeon Ben Yokhai at Meron
}

\section{E. W. G. Masterman}

To cite this article: E. W. G. Masterman (1919) A Jewish Feast: The Annual Feast of Rabbi Simeon Ben Yokhai at Meron, Palestine Exploration Quarterly, 51:3, 112-117, DOI: $10.1179 /$ peq.1919.51.3.112

To link to this article: http://dx.doi.org/10.1179/peq.1919.51.3.112

Published online: 20 Nov 2013.

Submit your article to this journal $\sqsubset$

Џll Article views: 7

Q View related articles $\square$ 
the Governor instructed his qualified assistants to study with great care a design for a balustrade which would reproduce as closely as possible the features of the chancel, which should enclose the elevated choir of a Constantinian Basilica.

When this work is accomplished it will be to the honour of the high authority who took the initiative amidst the preoccupations entailed by his position, and to the men of science and taste who carried it out.

The Palestine Exploration Fund is not likely to be indifferent to the fact that this brilliant improvement is due to English officers.

JERUSALEM, March, 1919.

Père L. H. VINCENT.

\title{
A JEWISH FEAST.
}

\section{THE ANNUAL FEAST OF RABBI SIMEON BEN YOKHAI AT MERON. ${ }^{1}$}

\author{
By E. W. G. Masterman, M.D., F.R.C.S.
}

ANNUAL festivities at sacred tombs are common to all the three great religions in Palestine. Thus, the "Holy fire" in the Church of the Holy Sepulchre draws thousands of Oriental Christians together every Eastertide, and at the same time the Moslems from all over the land pour down into the Jordan Valley to celebrate the Feast of Nebi Musa at the (to them) traditional tomb of Moses. Both these celebrations have been repeatedly described. The corresponding Jewish feasts held in Galilee are little known outside Palestine, but are certainly quite as picturesque, and, among Oriental Jews, are times of great rejoicings. These two annual spring festivals are, the one at the tomb of Rabbi Meyer Baal Nes, held on the thirtieth day after the Passover, at Tiberias, and that at the tomb of Rabbi Simeon ben Yokhai on the thirty-third and thirty-fourth days after the Passover, at Meron, on the slopes of

1 Reprinted, with kind permission of the Editor, from the Near East, Aug. 2, 1918. 
the Jebal Jermak to the west of Safed. The latter is the more ancient feast, but many Jewish pilgrims manage to attend both, and hundreds of Jews stream up from Tiberias-every donkey, mule, and horse available being requisitioned-to attend the great gathering at Meron. It is not my purpose to enter into any historical account of the gatherings, or of those in whose honour they are held, but as I had an opportunity of attending the Meron feast some years ago, and as, with the influx of new ideas into the land, it is to be feared that many of the picturesque features will fade away, I propose to narrate-from notes taken at the timemy impressions of the occasion.

We left Safed on Thursday, May 2, at 5 p.m. Pilgrims had been pouring along the road to Meron all the day long, and at 2.30 that afternoon a famous Torah (copy of the law) from the Chief Sephardim Synagogue had been carried in procession, its passage to Meron being celebrated by a collection of alms en route. This much-venerated Torah is said to have been stolen some centuries ago, and to have been carried to Constantinople; but from there it returned of its own accord a month or so later! When we took the road, there was one almost continuous line of people walking or riding to Meron. At an old cistern-Biresh Shih-about halfway, a tent had been erected, and bread and water were being distributed gratuitously to those in need. A few yards further on is a ruin reputed to be the tomb of Rabbi Yosëa Galilee; a number of Jews were collected together reciting prayers.

Our fresh horses steadily outstripped the jaded and overloaded beasts, each conveying the food and household utensils, as well as at times two or more members of a Jewish family.

Close to Meron itself we passed the Chief Rabbi of Safed, whose bowed and aged frame was swaying about on the back of an ass. A mounted Turkish soldier, with rifle to knee, rode in front for hi protection. A few yards farther and we found ourselves amids the excited crowds scattered around the tomb. Before we could dismount a group of three musicians commenced a musical welcome in our honour which we promptly diverted to greet the arrival of the more honourable visitor behind-the Chief Rabbi. As the setting sun left us but a few minutes more of daylight, we hastened to use its light to visit the tomb of the famous Hillel, on the hillside to the west. Here are shown the sarcophagi of the great teacher and of his thirty-six disciples-all, alas! to-day empty. It 
is a strange underground chamber with the sarcophagi on three sides, each with a massive stone lid. In the darkening interior we could see the drops of moisture gathering on the roof, to fall upon the puddles on the floor, while every sarcophagus was brimful of water. The damp, the gloom, and the semi-desertion of the site were in strange contrast to the flaring lights and noisy crowds gathering around the tomb of Simeon. The only visitors to Hillel's tomb were two Yemen Jews from Silwan (Siloam), who, like a large proportion of those in the neighbourhood, were unblushing mendicants.

Crossing some fields towards the site of the festive proceedings, we reached the rear of the Synagogue just as a burst of applause from the roof marked the conclusion of a sword dance by two Aleppo Jews. We then entered the outer court of the Synagogue. The centre was occupied by a booth sheltering the stalls of several provision sellers, and round this gyrated a vast moving crowd. By squeezing and pushing-and being pushed-we at length pressed our way into the shrine itself and found ourselves before the tomb of the saint. This, a raised oblong structure of whitewashed stone, occupied the south-east corner of the building, and was ablaze with the candles of the worshippers. A few pious Jews, in marked contrast to most of those present, were engaged in prayer. Nearer the centre of the Synagogue was the less honoured tomb of Rabbi Eliezer, Simeon's son. As we wandered about, an ever-increasing string of beggars attached themselves to us and we were not sorry to escape again into the open courtyard. Thence, we ascended a stone staircase to the surrounding gallery, from which the swaying multitude in the court below could be observed. Although all the front places had been taken hours before, one kind old Jewish matron made a place for me, from which I could look down for hours upon the proceedings. It was now growing dark, and the young folks on the roofs and galleries occupied themselves by throwing a stream of flaming green and red matches upon the heads of the dense and moving crowd. Some landed upon the straw mat, but not a few, impelled with surer aim, did visible damage to hats and clothes. The utmost good humour appeared to prevail, however, and I had many friendly greetings from happy faces. I only saw one quarrel, when a young man, apparently the worse for liquor, forcibly ejected a woman from a seat which he coveted. 
Two Jewish bands-fiddle, drum, and cornet-played, turn about, without cessation in friendly rivalry but barbaric discord, and circles of Jews revolved in the court below. Sometimes they would dance shoulder to shoulder, with arms closely intertwined, at other times they threw themselves about, frantically waving their arms up and down. The Ashkenazim Jews, with their long cloaks, furlined caps, their peyut, and their long ragged beards, looked most extraordinary, throwing themselves in wild contortions as they circled round in front of the Synagogue door. In another part, a circle of Sephardic (Spanish-speaking) Jews went through various forms of more dignified, though, perhaps more noisy, dance.

At times one could see in the semi-darkness swords being slowly waved, while at others a chorus in honour of Rabbi Simeon, accompanied by clapping of hands, would vary the programme. Suddenly the former group was joined by a man with a girl of about seven perched upon his shoulders. She was clad in white, with a gold braided cap on her head, and while she clung with all her might to her father's head, he twisted and turned and gyrated among the dancers with unwearied energy. We learned that she was a child who had during the last year been spared to her parents through a severe illness, and this was their way of returning thanks - probably in fulfilment of a vow made in the hour of anxiety. This father was soon joined by others bearing, shoulder-high, boys of three years old who had been brought to have their sidelocks trimmed by the Rabbis on the morrow. Some of these children seemed to be actually enjoying themselves-as, with us, such children enjoy bank-holiday outings, with all the attendant discomforts-but one could not help wondering what they would be like the next morning after such a shaking up in such an atmosphere at such an hour. The darkness was now deeper, and only a few lamps suspended over the court, supplemented by frequent fireworks, illuminated the scene. Presently, looking eastwards to the mounted mass of Safed, we saw amidst the twinkling town lights a number of brighter points, which we learned were bonfires lit there in honour of the feast.

About nine o'clock the excitement around us-on the Synagogue roof-deepened, and presently an iron brazier upon a pole, which had been filled with clothes saturated in olive oil, was ignited. A middle-aged Jew from Bokhara waved his torch with wild delight, holding it at times suspended over the dancing crowds below- 
illuminating a scene quite Dantesque-and at other moments shaking it recklessly over the people around him on the roof. The Turkish guards took speedy advantage of the illumination to detect and summarily eject any Moslems they found scattered among the crowd. When the flames flagged fresh clothes-now a kumbaz (cloak), then a kamis (shirt)-were thrown upon the top. The holder of the brazier became more and more reckless in his movements, and scattered clouds of sparks and blazing fragments of garments, while the packed multitude around him jumped and shouted in excitement. Once in wilful carelessness, to the great disgust of the Shammas in attendance, he brought the blaze almost in contact with the sacred adlakah, or bonfire, the kindling of which is the chief feature of the evening.

This bonfire consisted of a pile of garments saturated in pure olive oil arranged upon a pillar of stone about five feet high. Two such constructions are built upon the roof, one in honour of Simeon and one of Eliezer. Over each a Shammas (Synagogue servant) presided, and all the evening each was occupied in accepting offerings of garments and olive oil for the fire. While oil was being freely given, the attendants did no little business by selling at an enormously enhanced value, small quantities of it for its supposed healing virtues. As the time drew on the presentations of oil arrived with increasing rapidity.

About 9.30 there was a stir along the gallery, and a group appeared escorting the Chief Rabbi, whose duty it was to kindle the adlakah in honour of Rabbi Simeon. This privilege is annually sold, and this year it had been purchased for twenty-five Napoleons by a Jew in Russia, who, being unable to attend himself, had, as is customary, deputed the Chief Rabbi to act for him and kindle the fire in his name. The aged Rabbi was assisted to a step within reach of the bonfire, he then wound a silk scarf soaked in oil around a stick, and having kindled this from the brazier, attempted to light the oil-soaked mass of garments. They were somewhat slow to ignite, so the brazier itself was lowered until it almost rested upon the combustibles. Sparks flew in clouds and were thrown by the wind over the Chief Rabbi and his supporters; the fur-lined cap of the former, showing signs of ignition, was hurriedly removed, leaving him in his less dignified skull-cap. To us the old gentleman would have seemed to be in a very uncomfortable position but for the glimpses we caught of his earnest and delighted face at 
intervals as he actively poured streams of fresh oil upon the blazing flames. As the fire blazed a perfect frenzy seemed to take possession of the crowd, which, amid loud shouts, danced up and down or surged backwards and forwards. After a quarter of an hour the second fire-close to where we stood-was kindled without special ceremony from the first bonfire. Most of our neighbours gave themselves up to having a "good time," and roared, shouted and gesticulated with delight. In contrast to the majority we saw three aged dames peering from a recess close to the fire, whose scared and shining faces were animated by the deepest reverence, while their toothless jaws worked up and down with mumbled prayers.

A third beacon was now kindled, just over the entrance, near the tomb of Rabbi Isaac Nifhah, and shortly afterwards, as we were leaving, we saw a blazing brazier being carried up the hill to light yet another bonfire at the tomb of Rabbi Yohannan Sandlar.

We picked our way out of the noise and smoke into the quiet environs. As we mounted our horses the moon rose calm and still behind the mountains of Safed, to disappear as we descended the steep and rocky hill from Meron, to reappear once more as we pursued the quiet and now deserted road back to Safed.

We left the crowds to carry on, amidst growing excitement and licence, their semi-pagan ceremonies all the night through and for twenty-four hours beyond. Noise and crowds and blazes seem to appeal to the multitude everywhere under the patronage of various religions. The "Holy Fire" in Jerusalem presents almost identical features-similar disorderly and excited crowds, loud chants and shouts, and finally a blaze of light. A good old-fashioned "Guy Fawkes" day of half a century ago-originally a semi-religious demonstration-appeals to the same tastes.

It has been stated that at Meron costly garments and even jewellery are cast into the fire, but I saw nothing of this kind of offering, and, if such a custom existed, it is not continued now.

The second day of the feast is not so important as the first, but is marked by one custom peculiar to itself. Jews, on this occasion, bring their three-year-old boys to the tomb of Rabbi Yohannan in order that the Rabbis may cut their hair to make the beginnings of the peyut, or side locks, so greatly valued by the orthodox. 